\title{
THE INFLAMMATORY RESPONSE OF FISH TO HELMINTH PARASITES
}

\author{
DEZFULI B.S.*, LUI A.*, BOLDRINI P.**, PIRONI F.* \& GIARI L. *
}

\section{Summary :}

Fish serve as a good model for studying vertebrate immune systems because they have a relatively simple system. Descriptions of histopathological effects of helminth parasites on fish are few and far between with limited observations made on the identification of the inflammatory cells involved in the host reaction. Recently, two cell types found within teleosts received a great deal of attention, namely mast cells and rodlet cells. Fish mast cells also known as eosinophilic granule cells, are morphologically and functionally similar to their mammalian counterparts. Acute tissue damage causes mast cells degranulation and the release of mediators of inflammation, whereas, an increase in the number of these cells is usually found in chronically inflamed tissues. Rodlet cells, however, are exclusive to fish and are characterized by a distinct cell cortex and conspicuous inclusions, called rodlets, which accounts for their name. Piscidin has also been encountered within rodlet cells. As important cell types within the immune system of fish, both mast cells and rodlet cells have been seen to increase in number in infected fish, notably at the sites of pathogen attachment or infection. The present survey will provide data from studies with the light microscope on the response of mast cells and rodlet cells in a range of fish species (Anguilla anguilla, Oncorhynchus mykiss, Salmo trutta, Coregonus lavaretus) infected with a range of different parasite genera including representatives from the Digenea, Cestoda, Nematoda and Acanthocephala.

KEY WORDS : fish inflammation cells, mast cells, rodlet cells, helminth parasites.

T The digestive tract of many fish has been shown to be a favourite environment for the establishment and growth of pathogenic organisms. Endoparasitic helminths often induce inflammation and modification of the structure and function of local tissues (Castro, 1992). According to Sharkey (1992), the inflammation consists of a complex series of homeostatic mechanisms involving the immune, nervous and circulatory systems in response to tissue injury or infection. There are several published records on the essential role of enteric immune cells in inflammatory processes caused by parasitic helminths (Fairweather, 1997; Mai-

\footnotetext{
* Department of Biology \& Evolution, and ** Centre of Electron Microscopy, University of Ferrara, Italy.

Correspondence: Bahram S. Dezfuli, Department of Biology \& Evolution, University of Ferrara, St. Borsari, 46, I-44100 Ferrara, Italy. Tel.: 00390532455701 - Fax: 00390532455715 - E-mail: dzb@unife.it
}

frino et al., 1999; Dezfuli et al., 2000a, 2002a, b, 2003b; Bosi et al., 2005).

The cellular involvement in the inflammatory response in teleostean fish could be biphasic, initiating with an influx of neutrophils followed by latter arrival of monocytes/macrophages (Reite \& Evensen, 2006). In fish, two inflammatory cell types, namely mast cells and rodlet cells (RCs) are closely linked to other piscine inflammatory cells (Reite, 1997; Dezfuli et al., 2000b). Mast cells are found mainly in the connective tissue distributed throughput the body, and are more frequently found in tegumentary, urinary, respiratory, reproductive and gastrointestinal systems (Rocha \& Chiarini-Garcia, 2007). These cells have been noticed in all vertebrates, fish (Roberts et al., 1971; Reite, 1996), amphibians (Chiu \& Lagunoff, 1972), reptiles (Sottovia-Filho \& Taga, 1973), birds (Selye, 1965) and mammals (Galli, 1990; Chiarini-Garcia \& Pereira, 1999). Nevertheless, there is some controversy in the literature about mast cells existence in fish despite the fact that early reviews of the mast cells left little doubt that this cell type was present in all groups of vertebrates (Reite \& Evensen, 2006). In fish parasitized with helminths, greater number of mast cells was noticed in site of infection (Reite, 1997; Dezfuli et al., 2000b; Reite \& Evensen, 2006).

Regarding rodlet cells (RCs), they are characterized by a thick fibrous capsule, a basal nucleus, and conspicuous inclusions, called rodlets, which accounts for their name (Manera \& Dezfuli, 2004). Rodlet cells have been encountered in a wide range of tissues of freshwater and marine teleosts (Leino, 1974, 1982; Manera \& Dezfuli, 2004). However, despite the agreement on rodlet cells developmental stages, the location, migration, origin and role of these cells are controversial topics much debated since their first description more than 100 years ago (Reite \& Evensen, 2006). The possible function of RCs as immune cells was derived from studies that reported an increase in the number of these cells in fish parasitized with protozoan (Leino, 1996; Dezfuli et al., 2004) and metazoan parasites (Reite, 1997; Dezfuli et al., 2000b, 2002a, 2003a, 2007a). In the present survey, our main goal has been to study the histopathology in several fish species resulting 
from infection with a range of different helminth genera with light microscopy. Particular attention was paid to characterize the host cellular reaction against the parasite. Results of this investigation furnish further evidence on relationship between mast cells and rodlet cells and the role of both cell types in piscine inflammatory network.

\section{MATERIALS AND METHODS}

S pecimens of Coregonus lavaretus L., Salmo trutta L., Oncorbynchus mykiss (Walbaum, 1792), Anguilla anguilla $\mathrm{L}$., infected with a range of different parasite genera including representatives from the Digenea, Cestoda, Acanthocephala and Nematoda were sampled in different sites by electrofishing. Fish were anaesthetized using MS222 (Sandoz) and their spinal cords severed. The digestive tracts were removed, opened longitudinally and examined for helminthes which were recorded by number and location. Pieces of gut tissue measuring up to $15 \times 15 \mathrm{~mm}$ in area, with attached parasites, were excised from infected fish and fixed in chilled $\left(4^{\circ} \mathrm{C}\right)$ Bouin's for $8 \mathrm{~h}$. The samples were then transferred to $70 \%$ ethanol, dehydrated through an ethanol series, and prepared for paraffin embedding. Sections $(5 \mu \mathrm{m})$ were stained with haematoxylin-eosin, alcian blue/PAS, or Toluidine Blue.

For Semithin sections, host tissues measuring up to $7 \times$ $7 \mathrm{~mm}$ in area were fixed for $2.5 \mathrm{~h}$ in chilled $\left(4^{\circ} \mathrm{C}\right) 2 \%$ glutaraldehyde solution, in $0.1 \mathrm{M}$ sodium cacodylate $\mathrm{pH}$ 7.2. After $2.5 \mathrm{~h}$ the tissues were rinsed for $12 \mathrm{~h}$ in $0.1 \mathrm{M}$ sodium cacodylate buffer containing $5 \%$ sucrose. The samples were then post-fixed in $1 \%$ osmium tetroxide in the same buffer for $2 \mathrm{~h}$, dehydrated in graded ethanols, transferred to propylene oxide, and embedded in an Epoxy-Araldite ${ }^{\circledR}$ mixture. Semi-thin sections $(1.5 \mu \mathrm{m})$ were cut on a Reichert Om U 2 ultramicrotome and stained with Toluidine Blue or basic fuchsin. For comparison, tissues from several uninfected fish were processed with the parasitized samples. Light photomicrographs were taken using a Nikon microscope Eclipse 80i.

\section{RESULTS}

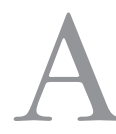

mong 32 Anguilla anguilla more than half was infected with the digenean Helicometra fasciata (Rudolphi, 1819). The intensity of infection ranged from 20 to several hundreds worms per host. The most heavily parasitized region of host alimentary canal was the intestine. Specimens of $H$. fasciata were noticed either free in the lumen or attached to the gut wall (Fig. 1). The digenean penetrates deeply through the intestinal folds with the anterior part of its body. Attachment is secured mainly by one sucker, while the other sucker attaches itself to a portion of intestinal villi and isolates it from the rest of the fold (Fig. 1). Concerning the relationship between rodlet cells (RCs) and digenean, most often the RCs were in the apex of intestinal villi, near the site of trematode sucker attachment or in the vicinity of the parasite body wall (Fig. 2). Frequently, rodlet cells had discharged part or almost all of their contents into the interface region between host and helminth body.

In some parasitized eels, the presence of nematode larvae was noticed on outer surface of the intestine, these larvae were identified as Contracaecum rudolphii (Hartwich, 1964). Later histological sections revealed the presence of nematode larvae also within the thickness of the gut wall (Fig. 3). Near the encysted larvae, rodlet cells were noticed in epithelium and mast cells were in submucosa very close to the larva (Fig. 3). Histopathological study on the intestines of 40 specimens of farmed rainbow trout, Oncorbynchus mykiss (Walbaum, 1792) showed that 25 were infected with the pseudophyllidean cestode Eubothrium crassum (Bloch, 1779). The cestodes were found attached by their scolices to the mucosal lining of the distal portion of the pyloric caeca. Within the caeca, the strobila was free in the lumen and tapeworm was found attached to the epithelium of the caecum by means of the scolex bothria (Fig. 4). Rodlet cells were observed in the mucosal epithelium (Fig. 5) in close proximity to the tegument of the parasite. Near the site of worm attachment mast cells of the stratum granulosum were numerous and exhibited granular depletion suggestive of a massive degranulation.

The hearts of 26 powan Coregonus lavaretus (L.) harboured metacercariae of the digenean trematode Ichthyocotylurus erraticus (Rudolphi, 1809). The vast majority of metacercariae were located either singly (Fig. 6) or as an aggregation of white cysts on the surface of the bulbus arteriosus. The capsule formed by the host's reaction to the parasite and its structure appeared to comprise a series of concentric whorls of fibroconnective elements (Fig. 6). Within the fibres, the presence of mast cells in close proximity of the trematode body wall was noticed (Fig. 6). In some hearts, there was fusion of the granules of the mast cells near parasite body.

In a sample of 25 Salmo trutta L., 20 specimens were infected with the acanthocephalan Echinorbynchus truttae (Schranck, 1788) (Fig. 7). Most acanthocephalans were in the anterior (near the pyloric caeca) and middle intestine. The majority of the worms did not cross the stratum granulosum (Fig. 7), but in several cases the proboscis penetrated the muscularis layer. Folds around the worm body remained intact, and in their epithelial layer a large number of rodlet cells (RCs) were 

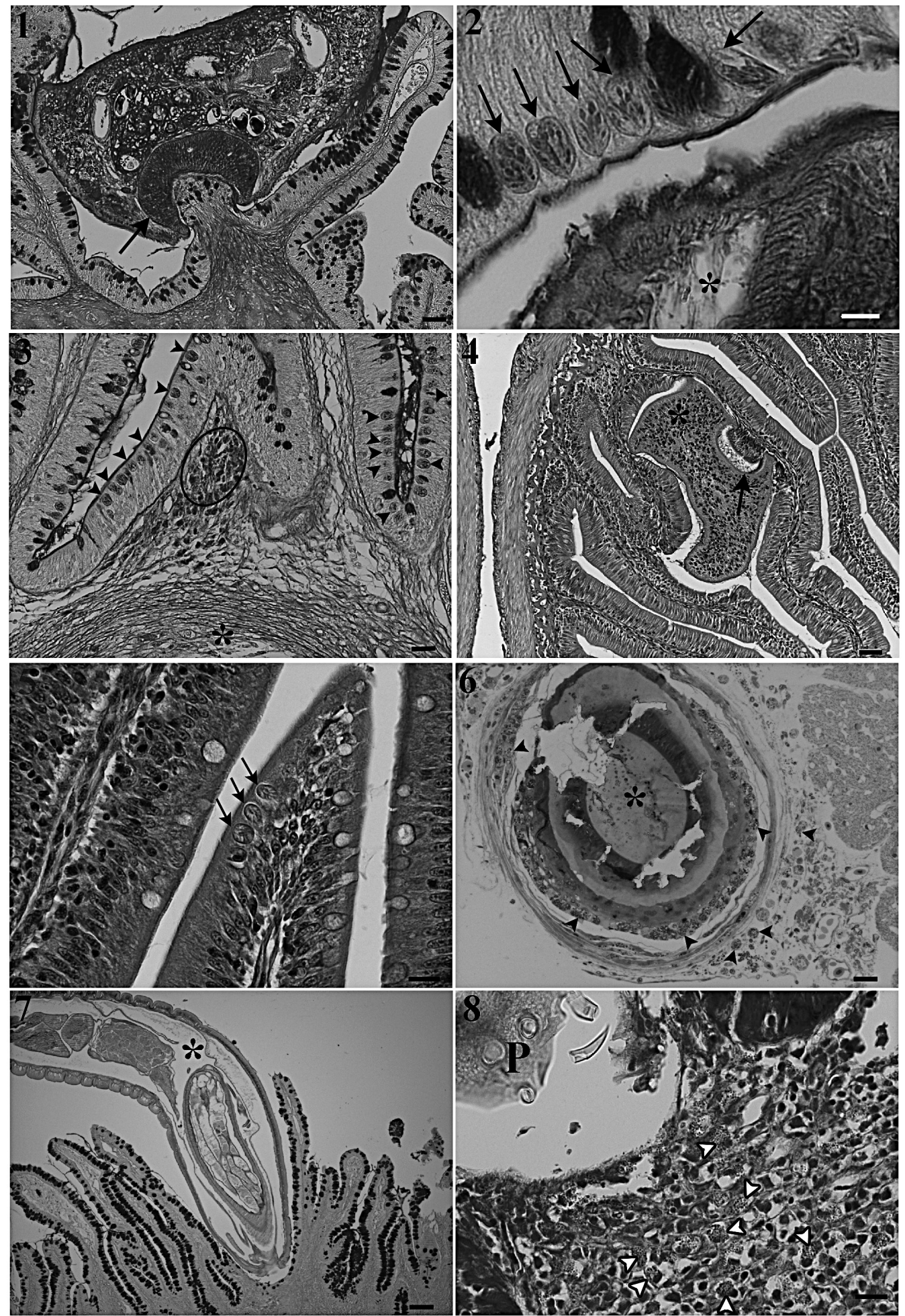

Figs 1-8. - Fig. 1. A specimen of Helicometra fasciata within eel intestinal fold. Inside the ventral sucker (arrow) the presence of a fragment of gut epithelium can be seen, scale bar $=60 \mu \mathrm{m}$. Fig. 2. Rodlet cells (arrows) in the apex of eel intestinal villi toward $\mathrm{H}$. fasciata body (asterisk), scale bar $=10 \mu \mathrm{m}$. Fig. 3. Numerous rodlet cells (arrow heads) in eel epithelium and high number of mast cells (circle) very close to encysted Contracaecum rudolphii larva (asterisk), scale bar $=30 \mu \mathrm{m}$. Fig. 4. A cross-section through a caecum of Oncorbynchus mykiss parasitized with Eubothrium crassum (asterisk). Attachment of the tapeworm scolex by its bothria (arrow) to the epithelium of the caecum is evident, scale bar $=60 \mu \mathrm{m}$. Fig. 5. Rodlet cells (arrows) noticed in the epithelium of the E. crassum-infected caecum, scale bar $=20 \mu \mathrm{m}$. Fig. 6. Coregonus lavaretus heart parasitized with Ichthyocotylurus erraticus metacercaria (asterisk), the cyst is surrounded by high number of host mast cells (arrow heads), scale bar $=30 \mu \mathrm{m}$. Fig. 7. Parasitized intestine of Salmo trutta with attached Echinorbynchus truttae (asterisk), in site of infection lack of intestinal folds is evident, scale bar $=150 \mu$ m. Fig. 8 . Numerous mast cells (white arrow heads) near the site of attachment of the proboscis (P), scale bar $=20 \mu \mathrm{m}$. 
observed. Numerous mast cells were noted in the tissues near the parasite trunk/body and around the proboscis (Fig. 8). In the stratum granulosum and in the muscularis layer, numerous mast cells were in close contact with the capillaries and the cells were observed in the outer layer of the endothelia as well as inside the blood vessels (not shown). Degranulation of the mast cells was common in the lamina propria (Fig. 8) and the stratum granulosum. The cells exhibited higher rates of degranulation in areas near the acanthocephalan proboscis (Fig. 8).

\section{DISCUSSION}

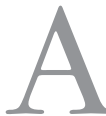

mong the helminths parasites of Coregonus, some records referring to a digenean trematode, $I c h$ thyocotylurus erraticus and mentioned that, high intensity of metacercarial of this worm in heart of fish can induce host mortality (Orecka-Grabda, 1991), as contrary, Blair $(1976,1977)$ regarding cercariae of British strigeoids (Digenea) suggested that the parasites can not be a direct cause of fish death.

Concerning the infected heart of a fish, changes in performance of heart in vitro was reported in rainbow trout parasitized with digenean Apatemon gracilis (Rudolphi, 1819) (Tort et al., 1987). According to Tort and collaborators, the cardiac output of infected hearts was $20-40 \%$ of that of healthy hearts. Of the records focusing specifically on Ichthyocotylurus erraticus in fish there are only two accounts (Orecka-Grabda, 1991; Dolezel \& Crompton, 2000), but, none of them provided adequate documentation of type of host cells involved in fish reaction. Herein Ichthyocotylurus erraticus metacercariae on (and in) heart of Coregonus lavaretus was surrounded by a reactive capsule produced by host fibroconnective tissue. The same capsule was noticed in heart and kidney of C. albula infected with I. erraticus (Orecka-Grabda, 1991), in infected heart of powan of Loch Lomond (Dolezel \& Crompton, 2000). During this study we documented the main type of cell scattered among the fibres within the capsule (i.e. mast cells) in interface region. Regarding mast cells, their nature is still a matter of debate (Reite, 2005; Reite \& Evensen, 2006). These cells are part of the host's inflammatory response and occur in site of parasite infection (Ferguson, 1989; Reite, 1998, 2005 see below).

Intestinal helminths of vertebrates can induce inflammation of the host digestive tract, resulting in altered gastrointestinal function, namely enhanced secretion and propulsive motility of the gut (Palmer \& Greenwood-Van Meerveld, 2001). Furthermore, helminths seriously disrupt structures of the gut wall and interrupt communications between the nervous and endocrine systems (Fairweather, 1997). One of the most important factors in the pathogenesis of gastrointestinal parasite infections is a reduction in the host feed intake (Houtert \& van Sykes, 1996; Mercer et al., 2000). Moreover, gut parasites also increase endogenous protein and fat losses, thus affecting growth rate of the host (Hiscox \& Brocksen, 1973).

There is a considerable body of information regarding the effects of helminth infection in animals and several well documented cases on the influence of enteric worms on host gut neuroendocrine and immune system (Fairweather, 1997; Bosi et al., 2005). Several studies on the effects of intestinal parasites have shown that the main detrimental consequences for the host species are localised at the site of infection (Hoste, 2001). Although most investigations have focused on parasitic infections in mammals (Fox, 1997; Roberts et al., 1999; Eysker \& Ploeger, 2000; Mercer et al., 2000), there are a few fishparasite based records. Of the studies that do exist for fish, the majority have been published by the authors of the current work (see Dezfuli et al., 2000a, 2002a, b, 2003b, 2004, 2007c; Bosi et al., 2004, 2005). In the present survey, a greater presence of two inflammatory cell types were noticed, rodlet cells and mast cells. With reference to rodlet cells, they are exclusive of fish and for over a century, fish histologists and pathologists have attempted to determine the origin and functions of these enigmatic cells. Contrasting points of view of the nature of rodlet cells (RCs) have been proposed since their first description by Thélohan (1892). The view that RCs are parasites was held by several authors after 1895 (Laguesse, 1895; Bannister, 1966; Mayberry et al., 1979; Viehberger \& Bielek, 1982; Bielek \& Viehberger, 1983; Richards et al., 1994). Authors that favoured the parasitic nature of RCs, for a long time believed that they were sporozoan (Mayberry et al., 1979). They based their arguments on electron microscope observations which they claimed gave confirmation that Rhabdospora thelohani (rodlet cell) belonged to the Apicomplexa (Mayberry et al., 1979). The main arguments of those claiming that RCs are parasites included: their numbers vary from fish to fish; often they cannot be found in all individuals of the same species; they can be encountered in different tissues of the same species. According to Leino (1974, 2001b), there are several factors which presumably influence the variance in RC numbers: fish species, crowding, season, and the ionic concentration of the water. Among past proponents of the parasitic nature of RCs, some have changed their opinion in favour of the argument that the RC is of teleost origin but, their inclusions - namely the rodlets - are parasitic (Barber \& Mills Westermann, 1986a, b; Fishelson \& Becker, 1999). The parasitic nature of RCs leaves many questions unanswered, for example, what is the reason for the absence of the characteristic apicomplexan sexual stages in the RCs? Why are the RCs enwrapped within a filamen- 
tous capsule instead of a distinct cyst? Why do these cells lack a specific tissue preference? Why do they have exceptionally wide distributions in fishes living in a great variety of environmental conditions (e.g. fresh and sea water)? None of the authors that support the idea that RCs are parasites, nor those that propose that the rodlet is a pathogen element, presented enough or convincing data to substantiate their interpretations. The literature on RCs as endogenous fish cells is extensive. Catton (1951) and Bullock (1963) and other investigators suggested that these cells resembled a type of granular leukocyte. On the other hand, several other researchers (Barrington, 1957; Bishop \& Odense, 1966; Wilson \& Westerman, 1967) concurred with Plehn's (1906a, b) suggestion of a glandular nature. In fact, ultrastructural study of these cells in several freshwater and marine teleosts supports the latter suggestion (Leino, 1974, 1996, 2001a, 2002; Flood et al., 1975; Dezfuli et al., 2000b, 2003a, 2007a, b, d). There are several points that favour the argument for the endogenous nature of these cells. Firstly, Lom argued (cited in Flood et al., 1975) that the wide distribution of RCs within the host tissues and among fish species is not a feature of Apicomplexa, which have a rigid tissue and host specificity. Second, RCs present morphological characteristics that are different from those of all known Apicomplexa. Third, there are several records of an increase in the number of RCs at the site of protozoan infection (Leino, 1996, 2001b; Dezfuli et al., 2004) and/or metazoan parasites (Dezfuli et al., 1998, 2000b, 2003a, 2007a, b; Reite, 1998).

The role of RCs as teleost inflammatory cells rarely has been studied, although some data were reported by Leino (1974, 1979, 1996) and Iger \& Abraham (1997). Results of several investigations on fish from the wild and on farmed fish suggest that RCs represent an inflammatory cell type closely linked to other piscine inflammatory cells, such as mast cells (Dezfuli et al., 1998, 2000b, 2003a, 2007a, b; Manera et al., 2001; Manera \& Dezfuli, 2004; Mazon et al., 2007; Reite \& Evensen, 2006).

Regarding fish mast cells called also eosinophilic granule cells, their presence has been area of controversy during last decades, despite the fact that early reviews of the mast cells literature left little doubt that this cell type was present in all classes of vertebrates (Reite \& Evensen, 2006). It is unclear if phagocytic cells of invertebrates gave rise to either granulocytes or macrophages of vertebrates. Although, lymphocytes, monocytes/ macrophages and other types of leucocytes encountered in mammals made their first appearance during evolution of fish (Reite \& Evensen, 2006). Accordingly, remarkable similarity in most leucocyte types of modern vertebrates is reflecting a common ancestry (Rowley, 1996). Nevertheless, most teleosts seem to have in alimentary canal, gills and other organs kind of cell that show functional and structural properties similar to those of mammalian mast cell (Vallejo \& Ellis, 1989; Lamas et al., 1991; Reite, 1997; Reite \& Evensen, 2006). Above similarities and response to known mast cell degranulating agents (i.e. Compound 48/80) and effects on vascular permeability have led investigators to suggest a role for these cells in the induction of inflammatory responses (Murray et al., 2007). These include vasodilatation, neutrophil attraction and migration and macrophage activation (Vallejo \& Ellis, 1989; Powell et al., 1991; Matsuyama \& Iida, 2001).

The specific role of mast cells in reaction to pathogen challenge has been sought for some time. Considerable descriptive records exist showing how these cells degranulate in response to exposure to a variety of pathogens or known degranulating agents (Powell et al., 1993; Reite, 1997; Paulsen et al., 2001; Schmale et al., 2004; Dezfuli et al., 2008). The functional similarity of the fish mast cells to mammalian mast cells has stimulated considerable research into determining the content of the cytoplasmic granules and hence an understanding of cellular function. Some surveys have suggested that mast cells secretions may have a role in attracting other types of cells (i.e. neutrophils) involved in the inflammatory process, especially during initial pathogen challenge (Matsuyama \& Iida, 2002; Reite \& Evensen, 2006). Other authors have detected specific neuromodulators (Dezfuli et al., 2000a) and enzymes including lysozyme (Sveinbjørnsson et al., 1996) within the granules of mast cells from fish exposed to infection by parasites and bacteria. Recently, specific antimicrobial peptides have been localized to mast cells (Silphaduang \& Noga, 2001; Iijima et al., 2003; Murray et al., 2003, 2007).

It is hoped that information provided by this paper will spur further research, nonetheless, the following investigations would contribute significantly to our knowledge about the RCs and mast cells in teleost. Further studies are required on the relationship of RCs and mast cells to pathogens. Indeed, it is necessary to intensify immunohistochemical investigations in search of a possible link between RCs, mast cells and other fish immune cells.

\section{ACKNOWLEDGEMENTS}

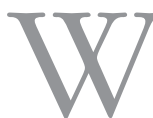

e thank E. Simoni University of Ferrara for technical assistance. This study was supported by grants from the Italian Ministry of the University and Scientific Research and Technology.

\section{REFERENCES}

BANNISTER L.H. Is Rhabdospora thelohani (Laguesse) a sporozoan parasite or a tissue cell of lower vertebrates? Parasitology, 1966, 56, 633-638. 
Barber D.L. \& Mills Westermann J.E. Comparison of the DNA of nuclei of rodlet cells and other cells in the chub Semotilus atromaculatus: hybridisation in situ. Canadian Journal of Zoology, 1986a, 64, 801-804.

Barber D.L. \& Mills Westermann J.E. The rodlet cell of Semotilus atromaculatus and Catostomus commersoni (Teleostei): studies on its identity using histochemistry and DNasi I-gold, RNasi A-gold, and S1 nuclease gold labelling techniques. Canadian Journal of Zoology, 1986b, 64, 804-813.

BARrington E.J.W. The alimentary canal and digestion, in: The physiology of fishes. Brown M. (ed.), Academic Press, New York, 1957, 109-162.

Bielek E. \& Viehberger G. New aspects on the "rodlet cell" in teleosts. Journal of Submicroscopic Cytology, 1983, 15, 681-694.

Bishop C.M. \& ODENSE P.H. Morphology of the digestive tract of the cod Gadus morhua. Journal of the Fisheries Research Board of Canada, 1966, 23, 1607-1615.

BlaIR D. Observations on the life-cycle of the strigeoids trematode, Apatemon (Apatemon) gracilis (Rudolphi, 1819) Szidat, 1928. Journal of Helminthology, 1976, 50, 125-131.

BlaIR D. A key to cercariae of British strigeoids (Digenea) for which the life-cycle are known, and notes on the characters used. Journal of Helminthology, 1977, 51, 155-166.

Bosi G., Di Giancamillo A., Arrighi S. \& Domeneghini C. An immunohistochemical study on the neuroendocrine system in the alimentary canal of the brown trout, Salmo trutta, L., 1758. General and Comparative Endocrinology, 2004, 138, 166-181.

Bosi G., Domeneghini C., Arrighi S., Giari L., Simoni E. \& DeZFULI B.S. Response of neuroendocrine system of the intestine of Leuciscus cephalus (L., 1758) naturally infected with Pomphorbynchus laevis Müller, 1776 (Acanthocephala). Histology \& Histopathology, 2005, 20, 509-518.

Bullock W.L. Intestinal histology of some salmonid fishes with particular reference to the histopathology of acanthocephalan infections. Journal of Morphology, 1963, 112, 2335.

CASTRO G.A. Intestinal physiology in the parasitized host: integration, disintegration, and reconstruction of systems. Annals of the New York Academy of Sciences, 1992, 664, 369-379.

CATTON W.T. Blood cell formation in certain teleost fishes. Blood, 1951, 6, 39-60.

Chiarini-Garcia H. \& Pereira F.M. A comparative study of lymph node mast cell populations in five marsupial species. Tissue E Cell, 1999, 31, 318-326.

Chiu H. \& Lagunoff D. Histochemical comparison of vertebrate mast cells. Histochemical Journal, 1972, 4, 135-144.

Dezfuli B.S., Capuano S. \& MANERA M. A description of rodlet cells from the alimentary canal of Anguilla anguilla and their relationship with parasitic helminths. Journal of Fish Biology, 1998, 53, 1084-1095.

Dezfuli B.S., Arrighi S., Domeneghini C. \& Bosi G. Immunohistochemical detection of neuromodulators in the intestine of Salmo trutta Linnaeus naturally infected with Cyathocephalus truncatus Pallas (Cestoda). Journal of Fish Diseases, 2000a, 23, 265-273.
Dezfuli B.S., Simoni E., Rossi R. \& Manera M. Rodlet cells and other inflammatory cells of Phoxinus phoxinus infected with Raphidascaris acus (Nematoda). Diseases of Aquatic Organisms, 2000b, 43, 61-69.

Dezfuli B.S., Giari L., Simoni E, Bosi G. \& Manera M. Histopathology, immunohistochemistry and ultrastructure of the intestine of Leuciscus cephalus (L.) naturally infected with Pomphorbynchus laevis (Acanthocephala). Journal of Fish Diseases, 2002a, 25, 7-14.

Dezfuli B.S., Pironi F., Giari L., Domeneghini C. \& Bosi G. Effect of Pomphorhynchus laevis (Acanthocephala) on putative neuromodulators in the intestine of naturally infected Salmo trutta. Diseases of Aquatic Organisms, 2002b, 51, 27-35.

Dezfuli B.S., Giari L., Konecny R., Jaeger P. \& Manera M. Immunohistochemistry, ultrastructure and pathology of gills of Abramis brama from Lake Mondsee, Austria, infected with Ergasilus sieboldi (Copepoda). Diseases of Aquatic Organisms, 2003a, 53, 257-262.

Dezfuli B.S., Giari L., Arrighi S., Domeneghini C. \& Bosi G. Influence of enteric helminths on the distribution of intestinal endocrine cells belonging to the diffuse endocrine system in Salmo trutta (L.). Journal of Fish Diseases, 2003b, 26, 155-166.

Dezfuli B.S., Giari L., Simoni E., Shinn A.P. \& Bosi G. Immunohistochemistry, histopathology and ultrastructure of Gasterosteus aculeatus (L.) tissues infected with Glugea anomala (Moniez 1887). Diseases of Aquatic Organisms, 2004, 58, 193-202.

Dezfuli B.S., Giari L. \& Shinn A.P. The role of rodlet cells in the inflammatory response in Phoxinus phoxinus brains infected with Diplostomum. Fish \& Shellfish Immunology, 2007a, 23, 300-304.

Dezfuli B.S., Capuano S., Simoni E., Giari L. \& Shinn A.P. Histopathological and ultrastructural observations associated with metacercarial infections of Diplostomum phoxini (Faust, 1918) (Digenea) in the brains of minnows, Phoxinus phoximus. Diseases of Aquatic Organisms, 2007b, 75, 51-59.

Dezfuli B.S., Pironi F., Shinn A.P., Manera M. \& Giari L. Histopathology and ultrastructure of Platichthys flesus naturally infected with Anisakis simplex s.l. larvae (Nematoda: Anisakidae). Journal of Parasitology, 2007c, 93, 1416-1423.

Dezfuli B.S., Capuano S., Simoni E., Previati M. \& Giari L. Rodlet cells and the sensory systems in zebrafish (Danio rerio). The Anatomical Record (Part A), 2007d, 290, 367374.

Dezfuli B.S., Giovinazzo G., Lui A. \& Giari L. Inflammatory response to Dentitruncus truttae (Acanthocephala) in the intestine of brown trout. Fish \& Shellfish Immunology, 2008, in press.

Dolezel M.C. \& CRompton D.W.T. Platyhelminth infection in powan Coregonus lavaretus (L.), from Loch Eck and Loch Lomond, Scotland. Helminthologia, 2000, 37,147-152.

Eysker M. \& Ploeger H.W. Value of present diagnostic methods for gastrointestinal nematode infections in ruminants. Parasitology, 2000, 120, S109-S119.

FAIRWEATHER I. Peptides: an emerging force in host response to parasitism, in: Parasites and pathogens: effects on host 
hormones and behaviour. Beckage N.E. (ed), Chapman \& Hall, New York, 1997, 113-139.

FErGuson H.W. Systemic pathology of fishes. Iowa State University Press, Ames, 1989.

Fishelson L. \& BECKER K. Rodlet cells in the head and trunk kidney of the domestic carp (Cyprinus carpio): enigmatic gland cells or coccidian parasites? Naturwissenschaften, 1999, 86, 400-403.

Flood M.T., Nigrelli R.F. \& Gennaro J.F.Jr. Some aspects of the ultrastructure of the 'Stäbchendrüsenzellen', a peculiar cell associated with the endothelium of the bulbus arteriosus and with other fish tissue. Journal of Fish Biology, 1975, 7, 129-138.

Fox M.T. Pathophysiology of infection with gastrointestinal nematodes in domestic ruminants: recent developments. Veterinary Parasitology, 1997, 72, 285-308.

GaLLI S.J. New insights into "The riddle of the mast cells": Microenvironmental regulation of mast cells development and phenotypic heterogeneity. Laboratory Investigation, $1990,62,5-33$.

Hiscox J.I. \& BROCKSEN R.W. Effects of a parasitic gut nematode on consumption and growth in juvenile rainbow trout (Salmo gairdneri). Journal of the Fisheries Research Board of Canada, 1973, 30, 443-450.

Hoste H. Adaptive physiological processes in the host during gastrointestinal parasitism. International Journal for Parasitology, 2001, 31, 231-244.

HOUTERT M.F.J. \& van SYKes A.R. Implications of nutrition for the ability of ruminants to withstand gastrointestinal nematode infections. International Journal for Parasitology, 1996, 26, 1151-1168.

Iger Y. \& ABraham M. Rodlet cells in the epidermis of fish exposed to stressors. Tissue \& Cell, 1997, 29, 431-438.

Ijima N., Tanimoto N., Emoto Y., Morita Y., Uematsu K., MuraKAMI T. \& NAKAI T. Purification and characterization of three isoforms of chrysophsin, a novel antimicrobial peptide in the gills of the red sea bream, Chrysophrys major. European Journal of Biochemistry, 2003, 270, 675-686.

LAGuEsse E. Les "Stäbchendrüsenzellen" (M. Plehn) sont des sporozoares parasites. Anatomische Anzeiger, 1895, 28, 414-416.

Lamas J., Bruno D.W., Santos Y., Anadon R. \& Eluis A.E. Eosinophilic granular cell response to intraperitoneal injection with Vibrio anguillarum and its extracellular products in rainbow trout, Oncorbynchus mykiss. Fish \& Shellfish Immunology, 1991, 1, 187-194.

LEINO R.L. Ultrastructure of immature, developing and secretory rodlet cells in fish. Cell \& Tissue Research, 1974, 155, 367-381.

LEINO R.L. Aspects of the fine structure, cytochemistry and distribution of teleost rodelt cells. Ph. D. thesis, Union Institute, Cincinnati, Ohio, 1979.

LEINO R.L. Rodlet cells in the gill and intestine of Catostomus commersoni and Perca flavescens: a comparison of their light and electron microscopic cytochemistry with that of mucous and granular cells. Canadian Journal of Zoology, 1982, 60, 2768-2782.
LEINO R.L. Reaction of rodlet cells to a myxosporean infection in kidney of the bluegill, Lepomis macrochirus. Canadian Journal of Zoology, 1996, 74, 217-225.

LEINO R.L. Formation and release of the secretory product in rodlet cells. First International Rodlet Cell Workshop. June 14-16, Ferrara, Italy, 2001a, 6.

LEINO R.L. Seasonal increases of rodlet cells and other celltypes in Percid gills: association with parasitic infections. First International Rodlet Cell Workshop. June 14-16, Ferrara, Italy, 2001b, 10.

LEINO R.L. The contractile mechanism and "holocrine" secretion in teleost rodlet cells. $53^{\text {rd }}$ Annual Proceeding of the Scandinavian Society for Electron Microscopy, June 12-15, Tampere, Finland, 2002, 74-76.

Maifrino L.B.M., Liberti E.A. \& De Souza R.R. Vasoactive intestinal peptide- and substance P-immunoreactive nerve fibres in the myenteric plexus of mouse colon during the chronic phase of Trypanosoma cruzi infection. Annals of Tropical Medicine and Parasitology, 1999, 93, 49-56.

Manera M. \& Dezfuli B.S. Rodlet cells in teleosts: a new insight into their nature and functions. Journal of Fish Biology, 2004, 65, 597-619.

Manera M., Simoni E. \& Dezfuli B.S. The effect of dexamethasone on the occurrence and ultrastructure of rodlet cells in goldfish. Journal of Fish Biology, 2001, 59, 1239-1248.

Matsuyama T. \& Iida T. Influence of tilapia mast cell lysate on vascular permeability. Fish \& Shellfish Immunology, 2001, 11, 549-556.

Matsuyama T. \& Iida T. Tilapia mast cell lysates enhance neutrophil adhesion to cultured vascular endothelial cells. Fish E Shellfish Immunology, 2002, 13, 243-250.

Mayberry L.F., Marchiondo A.A., Ubelaker J.E. \& Kazic D. Rhabdospora thelohani Laguesse, 1895 (Apicomplexa): new host and geographic records with taxonomic consideration. Journal of Protozoology, 1979, 26, 168-178.

Mazon A.F., Huising M.O., Taverne-Thiele A.J., Bastiaans J. \& Verburg-VAn Kemenade B.M.L. The first appearance of rodlet cells in carp (Cyprinus carpio L) ontogeny and their possible roles during stress and parasite infection. Fish $\varepsilon$ Shellfish Immunology, 2007, 22, 27-37.

Mercer J.G., Mitchell P.I., Moar K.M., Bissett A., Geissler S., BRUCE K. \& Chappell L.H. Anorexia in rats infected with the nematode, Nippostrongylus brasiliensis: experimental manipulations. Parasitology, 2000, 120, 641-647.

Murray H.M., Gallant J.W. \& Douglas S.E. Cellular localization of pleurocidin gene expression and synthesis in winter flounder gill using immunohistochemistry in situ hybridization. Cell and Tissue Research, 2003, 312, 197202.

Murray H.M., Leggiadro C.T. \& Douglas S.E. Immunocytochemical localization of pleurocidin to the cytoplasmic granules of eosinophilic granular cells from the winter flounder gill. Journal of Fish Biology, 2007, 70, 336-345.

ORECKA-GRABDA T. Remato- and histopathological changes in the whitefish (Coregonus albula (L.) invaded by metacercariae of Cotylurus erraticus (Syn. Ichthyocotylurus) (Rufolphi, 1809). Fish Pathology, 1991, 221, 3-19. 
Palmer J.M. \& Greenwood-Van Meerveld B. Integrative immunomodulation of gastrointestinal function during enteric parasitism. Journal of Parasitology, 2001, 87, 483-504.

Paulsen S.M., Sveinbjørnsson B. \& Robertsen B. Selective staining and disintegration of intestinal eosinophilic granule cells in Atlantic salmon after intraperitoneal injection of the zinc chelator dithizone. Journal of Fish Biology, 2001, 58, 768-775.

PLEHN M. über eigentmüliche Drüsenzellen im Gefä \& system und in aderen Organen bei Fischen. Anatomische Anzeiger, 1906a, 28, 192-203.

PLEHN M. Drüsenzellen oder parasiten? Anatomische Anzeiger, 1906b, 29, 152-157.

Powell M.D., Wright G.M. \& Burka J.F. Degranulation of eosinophilic granule cells induced by capsaicin and substance $\mathrm{P}$ in the intestine of the rainbow trout, Oncorbynchus mykiss (Walbaum). Cell and Tissue Research, 1991, 266, 469-474.

Powell M.D., Briand H.A., Wright G.M. \& Burka J.F. Rainbow trout (Oncorhynchus mykiss Walbaum) intestinal eosinophilic granule cell (EGC) response to Aeromonas salmonicida and Vibrio anguillarum extracellular products. Fish E Shellfish Immunology, 1993, 3, 279-289.

REITE O.B. The mast cell nature of granule cells in the digestive tract of the pike, Esox lucius: similarity to mammalian mucosal mast cells and globule leucocytes. Fish \& Shellfish Immunology, 1996, 6, 363-369.

REITE O.B. Mast cells/eosinophilic granule cells of salmonids: staining properties and responses to noxious agents. Fish E Shellfish Immunology, 1997, 7, 567-584.

ReITE O.B. Mast cell eosinophilic granule cells of teleostean fish: a review focusing on staining properties and functional responses. Fish \& Shellfish Immunology, 1998, 8, 489513.

REITE O.B. The rodlet cells of teleostean fish: their potential role in host defence in relation to the role of mast cells/eosinophilic granule cells. Fish \& Shellfish Immunology, 2005, 19, 253-267.

ReIte O.B. \& EvENSEN $\varnothing$. Inflammatory cells of teleostean fish: a review focusing on mast cells/eosinophilic granule cells and rodlet cells. Fish \& Shellfish Immunology, 2006, 20, 192-208.

Richards D.T., Hoole D., Arme C., Lewis J.W. \& Ewens E. Phagocytosis of rodlet cells (Rhabdospora thelohani Laguesse, 1895) by carp (Cyprinus carpio L.) macrophages and neutrophils. Helminthologia, 1994, 31, 29-33.

Roberts H.C., Hardie L.J., Chappell L.H. \& Mercer J.G. Parasite-induced anorexia: leptin, insulin and corticosterone responses to infection with the nematode, Nippostrongylus brasiliensis. Parasitology, 1999, 118, 117-123.

Roberts R.J., Young H. \& Milne J.A. Studies on the skin of plaice (Pleuronectes platessa L.) 1. The structure and ultrastructure of normal plaice skin. Journal of Fish Biology, 1971, 4, 87-98.

ROCHA J.S. \& ChIARINI-GARCIA H. Mast cell heterogeneity between two different species of Hoplias sp. (Characiformes: Erythrinidae): response to fixatives, anatomical distribution, histochemical contents and ultrastructural features. Fish \& Shellfish Immunology, 2007, 22, 218-229.
Rowley A.F. The evolution of inflammatory mediators. Mediators of Inflammation, 1996, 5, 3-13.

Schmale M.C., Vicha D. \& CaCal S.M. Degranulation of eosinophilic granule cells in neurofibromas and gastrointestinal tract in the bicolor damselfish. Fish \& Shellfish Immunology, 2004, 17, 53-63.

SELYE H. The mast cell. Buttheworths, London, 1965.

SHARKEY K.A. Substance P and calcitonin gene-related peptide (CGRP) in gastrointestinal inflammation. Annals of the New York Academy of Sciences, 1992, 664, 425-442.

Silphaduang U. \& Noga E. Peptide antibiotics in mast cells of fish. Nature, 2001, 414, 268-269.

SotTovia-Filho D. \& TAga R. Morphological and histochemical study of granular acidophilic cells in the connective tissue of some ophidians. Archivum Histologicum Japonicum, 1973, 36, 79-84.

Sveinbjørnsson B., Olsen R. \& Paulsen S. Immunocytochemical localization of lysozyme in intestinal eosinophilic granule cells (EGCs) of Atlantic salmon, Salmo salar L. Journal of Fish Diseases, 1996, 19, 349-355.

ThèLohan P. Sur des sporozoaires indéterminés parasites des poissons. Journal d'Anatomie et Physiologie Paris, 1892, 28, 163-171.

Tort L., Watson J.J. \& Priede G.I. Changes in in vitro heart performance in rainbow trout, Salmo gairdneri Richardson, infected with Apatemon gracilis (Digenea). Journal of Fish Biology, 1987, 30, 41-347.

VALLEJO A.N. \& ElLIS A.E. Ultrastructural study of the response of eosinophilic granule cells to Aeromonas salmonicida extracellular products and histamine liberators in rainbow trout, Salmo gairdneri Richardson. Developmental and Comparative Immunology, 1989, 13, 133-148.

VIEHBERger G. \& BieleK E. Rodlet-cells: gland cell or protozoon? Experientia, 1982, 38, 1216-1218.

Wilson J.A.F. \& Westerman R.A. The fine structure of the olfactory mucosa and nerve in the teleost Carassius auratus L. Zurnal Zellforsch, 1967, 83, 196-206. 